\title{
Protectivity Versus Productivity And Economic Growth: Empirical Evidence From Selected Countries
}

Hamid Shahrestani, Ohio University, USA

Nahid Kalbasi Anaraki, Islamic Azad University, Iran

\begin{abstract}
This paper tries to cast light on the effects of terrorism on some macroeconomic variables at the international level. Using the Generalized Method of Moment (GMM) we investigate the effects of terrorism on such variables as GDP growth, foreign direct investment (FDI) and total factor productivity (TFP) with cross section data of 2005 for a sample of both developed and developing countries. The results suggest that terrorism has adversely and significantly affected economic growth, FDI and TFP around the world. In line with Abadie and Gardeazabal (2007) we find that once the effects of other country-specific characteristics such as country risk, good governance, and restrictions on FDI are taken into account these results are still robust.
\end{abstract}

Keywords: total factor productivity, protectivity, terrorism, country risk, good governance, economic growth, Foreign Direct Investment (FDI), Generalized Method of Moment (GMM),

\section{INTRODUCTION}

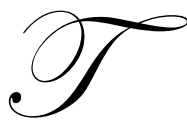

hough some economists argue that terrorism does not have a large effect on economic activities and productivity (see, e.g. Becker 2001), many empirical studies on the consequences of terrorism typically show large adverse effects on macroeconomic variables. Among others, Abadie and Gardeazabal (2005), Chen and Siems (2004), Frey, et al. (2004), Pshisva and Suarez (2004) find large devastating effects of terrorism on macroeconomic variables.

Terrorism has been most succinctly defined as "the intentional use of, or threat to use violence against civilians or against civilian targets, in order to attain political aims. During the past 35 years, the world has witnessed nearly 20,000 terrorist incidents, ranging from the hostage taking during the 1972 Munich Olympics to the 2005 tourist bombings in Bali. These incidents have resulted in more than 90,000 casualties worldwide.

Terrorism affects a country's economy in different ways. First, the capital stock is reduced significantly as a result of terrorism. Second, terrorism induces higher level of uncertainty, which undermines investment decisions. Third, terrorism invokes an increase in safety expenditures, drawing resources from productive sectors to counterterrorism activities and safety expenditures. Finally, it adversely affects foreign direct investment (FDI) due to higher level of uncertainty.

The 9/11 attacks, as part of Al Qaeda's strategy to disrupt western economies not only imposed both direct and secondary costs on the United States but on some other nations. The immediate costs were the physical damage, loss of lives and earnings, slower world economic growth, and capital losses on the stock markets. Indirect costs included higher insurance and shipping fees, diversion of time and resources away from enhancing productivity to protecting and insuring property, public loss of confidence, and reduced demand for travel and tourism. In a broader sense, the 9/11 attack led to the Global War on Terrorism, which in turn emboldened terrorism and perhaps reinforced them to attack Bali, Spain, Morocco, and Saudi Arabia. 
Indeed, the September 11 terrorist attacks on the United States have been widely linked with economics, both as cause and effect. Most notably, concerns have been widespread that the attacks would themselves trigger a deep recession in the US, which would quickly spill over globally. This concern has been materialized since 2005 . Although the US may already have been in recession prior to September 11, it is clear that the recent downturn has been exacerbated by the attacks.

Many urban residents and officials are worried that the combined impact of the recent recession and ongoing terrorist threats may have a devastating effect on the economic growth and other macroeconomic variables. This paper attempts to shed light on these concerns by examining the impact of terrorism incidents on such variables as economic growth, FDI and TFP, through implementing an endogenous growth model using Generalized Method of Moment (GMM) technique.

Indeed, not only the macroeconomic variables have been adversely affected by terrorism incidents but also stock markets have been considerably affected. The initial reaction of the financial markets was a "flight to quality." Equity prices tumbled. Spreads between corporate and government bond yields, as well as spreads between emerging market and US bond index yields widened. Monetary policy was eased aggressively, with central banks around the world lowering interest rates substantially in the weeks following the attacks. In the United States, the fiscal response was also swift. On 14 September, just three days after the attacks, Congress cleared a $\$ 40$ billion emergency spending package. A few days later, Congress authorized $\$ 5$ billion as direct grants plus $\$ 10$ billion in federal loan guarantees for the US airlines. Limited discretionary fiscal stimulus actions were taken in other OECD countries, not least because many of them had less room for maneuver. State aids were granted to airlines in the European Union as compensation for the losses resulting directly from the four-day closure of US airspace.

Even though the strong policy response mitigated the short-term direct impact, medium-term implications from the attacks should not be under-estimated. Though little research has been carried out on the long-term impact of terrorism, it appears that three important consequences have occurred: insurance coverage for terrorism-related activities has increased considerably; pressure is mounting to tighten security at the borders and screen the vast flows of merchandise entering countries; and last not least, public spending on security and military operations is on the rise. All these counter terrorism activities have had huge impacts on macro-economic variables, leading to a downturn in western world, particularly in the U.S.

\section{ESTIMATED COSTS OF TERRORISM}

Following the terrorist attacks, the already weak international economy was weakened further. The aftershocks of 9/11 were felt immediately in foreign equity markets, in tourism and travel, in consumer attitudes, and in temporary capital flight from the United States. Central bank authorities worldwide reacted by injecting liquidity into their financial systems. Still, the downturn in business conditions became more generalized and most of the world dropped into a synchronous recession - from 4.1\% world economic growth in 2000 to $1.4 \%$ in 2001 . By late 2002, aggressive reflationary fiscal and monetary policy in the United States and a booming Chinese economy led into recovery. The 2001 recession turned into a weak economic recovery with world growth of $1.9 \%$ in 2002 and $2.7 \%$ in 2003 - still anemic when compared with the growth rate of $2.3 \%$ in 1998 during the worst of the Asian financial crisis. For 2004, the recovery picked up speed and its strength broadened with growth of $4.6 \%$, even though by mid-2004, the world was hit with petroleum prices exceeding $\$ 40$ per barrel. This growth was stagnant in 2005. Though the world experienced slightly higher growth rate in 2006, it started a downward trend in early 2007 due to the US economy downturn, which was exacerbated in 2008 by spreading out these effects around the world.

But how much did 9/11 bring down world growth rates? Prior to $9 / 11$, major econometric forecasts expected that real GDP for the world to grow at $2.8 \%$ in 2001 and $3.1 \%$ in 2002 . However, after 9/11, the world GDP actually grew by $1.4 \%$ in 2001 and $1.9 \%$ in 2002. In the aftermath of $9 / 11$, therefore, actual growth came in at approximately 1 percentage point below expectations. Not all of this, of course, can be attributed to 9/11, but a 1 percentage point decline in the global GDP amounted to about $\$ 300$ billion less in world production and income in 2002. Subsequent terrorist attacks also have affected economic growth. The negative macroeconomic consequences 
of terrorism for developing nations due to reduced trade, investment and tourism seem to be huge. For instance, the 2002 Bali bombings reduced Indonesia's growth rate by an estimated 1 percentage point.

Another channel through which terrorism activities affect the economy is through increased private sector costs arising from a heightened perception of the threat from terrorism and the increased probability of costs of such attacks should they occur. Some of this is reflected in rising insurance costs, enhanced measures to ensure security of shipments, and in reduced travel and tourism. What cannot be measured is the decrease in productivity by individuals arising from lost time, greater hassles and general anxiety caused by the new security environment. In Europe, 36\% of companies recently surveyed the perception that terrorists deliberately target their organization or staff - 93\% believed that the war in Iraq had increased the threat. Yet the survey found out that $77 \%$ of organizations spend less than two percent of their global revenues on the security.

Following 9/11, in the United States, prices for terrorism insurance for property soared. In 2002, prices moderated, particularly after Congress passed the Terrorism Risk Insurance Act. With this federal backstopping of insurance claims in the United States through 2005, about 4.36\% of premiums on property are to cover terrorism risks. In Europe, following 9/11, commercial property and liability insurance rates rose by about $30 \%$ on average, with "target" structures (e.g. chemical and power plants, iconic office buildings) showing steeper increases. In response to rising insurance rates for aviation insurance, the European Union took measures that allowed member States either to pay insurance premiums linked to the "risk of war and terrorism for their airline companies or to grant them a State guarantee against such risk. Industry experts expected security-inspired measures to amount to between 1 and $3 \%$ of the value of shipments. The travel and tourism industry was hit particularly hard by $9 / 11$ and subsequent terrorism. Although most of the funds not spent on travel and tourism is spent elsewhere, the adjustment costs for the industry and economy can be significant. U.S. exports of travel services (foreign tourists visiting the United States) dropped by $12 \%$ in 2001 and $4 \%$ in 2002. Employment in U.S. industries related to travel and tourism in 2002 was down by 270,000 persons from 2001. Despite the government assistance ( $\$ 15$ billion emergency assistance package in 2001), several airlines declared bankruptcy.

To combat terrorism, public spending on homeland security and military operations has raised significantly in the United States and to a lesser extent in other OECD countries. Private sector spending is likely to be on the rise as well to improve the security of premises, employees and information. This may crowd out the accumulation of productive capacity, increase the cost of capital, raise wages and divert research and development (R\&D) activities toward military projects. Therefore, the benefits associated with the peace dividend may be reduced. Rough calibrations suggest that an increase in public military-security spending by 1 percent of GDP and private security spending by 0.5 per cent of GDP would reduce output by about 0.7 percent after five years. Hence, the step-increase in anti-terrorism spending ought to be accompanied by a hard look at the costs and benefits of other military programs, along the lines of what is intended more generally in the budget for non-defence spending. In addition, tighter security may reduce the level of productivity as, for instance, waiting times lengthen at airports, employees are threatened by terrorist threats, and etc.

\section{LITERATURE REVIEW}

Among others, Enders and Sandler (1996) have investigated the effects of terrorism on capital flows across countries. Using a VAR technique they estimate a negative effect of terrorism on FDI for Spain for the period 197691 and a negative effect for Greece for the period 1975-91.

As illustrated by Abadie and Gardeazabal (2005) beyond increasing uncertainty, terrorism reduces expected return to investment. According to their results, terrorism affects the stock of international investment in any particular country. They obtain empirical evidence on the open economy channel of terrorism by looking at the relationship between net foreign direct investment (FDI) and terrorism in a sample of cross-section countries. Using an AK production function, in their study, terrorism affects capital accumulation through three different channels. First, terrorism directly destroys part of capital stock of a country. Second, it changes the process that determines the return to capital, affecting the overall investment position of the individuals in the world economy. Finally, terrorism affects the allocation of productive capital not only across countries but also across different industries inside the 
countries. They measure the variance of net FDI stock explained by terrorism risk. Their results suggest that in an integrated world economy, terrorism may induce large movements of capital across countries. The empirical evidence based on cross-country regressions indicates that terrorism risk depresses net foreign investment positions. This relationship is robust to the introduction of demographic factors, country specific risk index, governance indicators and other financial and macroeconomic factors such as per capita GDP and FDI restrictions, which might determine the country's FDI position.

Barth et al. (2006) examine the impact of terrorism on economic growth and capital formation and conjecture that terrorism is associated with adverse effects on overall economic activity. Terrorist incidents can trigger short-lived adverse reactions in financial markets (Chen and Siems, 2004; Elder and Melnick, 2004), but the evidence for the long-run impact of terrorism is less compelling (Becker and Murphy, 2001; Abadie and Gardeazabal, 2003 and 2005; Bloomberg, Hess, and Orphanides, 2004). Using terrorism data from the 2005 MIPT terrorism knowledge database, which integrates more than 20,000 terrorism incidents from various sources, researchers made several empirical estimations based on cross-sectional and period fixed-effects regressions with White-heteroskedasticity consistent standard errors. The main findings of Barth et al. are categorized by four specifications that include a set of control variables and four different measures of terrorism. The higher the number of terrorism incidents per million population, the lower the real GDP per capita growth, the lower the capital formation as a percentage of GDP, the higher the fatalities and injuries per \$U.S. billion GDP, and the lower the capital formation as a percentage of GDP. Their results show that terrorism is indeed associated with adverse economic effects. Put differently, terrorism incidents have a negative and significant impact on economic growth.

Abadie and Gardeazabal (2007) argue that mobility of productive capital in an open economy may account for much of the difference between the direct and the equilibrium impact of terrorism. They use a simple econometric model to show that terrorism may have a large impact on the allocation of productive capital across countries, even if it represents a small fraction of the overall economic risk. The model emphasizes that, in addition to increasing uncertainty, terrorism reduces the expected return to investment. As a result, changes in the intensity of terrorism may cause large movements of capital across countries if the world economy is sufficiently open, so international investors are able to diversify other types of country risks. Using a unique dataset on terrorism and other country risks, they find that higher levels of terrorist risks are associated with lower levels of net foreign direct investment positions, even after controlling for other types of country risks. According to their results, a standard deviation increase in the terrorist risk is associated with a fall in the net foreign direct investment position of about 5 percent of GDP. The magnitude of the estimated effect is relatively huge, which suggests that the open-economy channel impact of terrorism is, indeed, substantial.

Nevertheless, none of the abovementioned empirical studies has captured the effects of terrorism on productivity growth. Many developed and developing countries have allocated considerable amount of budget for counter-terrorism activities since 2001 to create safety in universities, airports, borders, and etc. This flow of resources from productive activities to non-productive sectors has affected the total factor productivity, among other macroeconomic variables, substantially. Indeed, one of the novel features of our study is that not only it captures the effects of terrorism on GDP growth and FDI, but it encompasses the effects on total factor productivity by using Generalized Method of Moment (GMM) technique.

\section{HYPOTHESIS}

This paper tries to investigate to what extent terrorism affect economic growth, FDI and TFP at the international level. We use Generalized Method of Moment (GMM) with cross-section data of 2005 for a sample of 30 developed and developing countries, in different regions, to demonstrate how terrorism incident does affect the GDP growth, FDI and TFP worldwide. We use the following endogenous growth model for the selected countries to capture the effects of terrorism on economic growth. 


$$
G \stackrel{0}{D} P=a_{0}+a_{1} K+a_{2} L+a_{3} \text { Schooling }+a_{4} \pi+a_{5} \text { terrorism }+a_{6} R+a_{7} G G+a_{8} D u m m y
$$

\section{0}

Whereas $G D P$ represents GDP growth, $K$ capital stock, $L$ labor force, Schooling secondary schooling, $\pi$ CPI inflation, terrorism the number of terrorism incidents in each country, $R$ country risk ranking, $G G$ good governance and finally Dummyrepresents a dummy variable, 1 for developed countries and zero for developing countries.

Since the terrorism has affected FDI in a similar way we also try to capture the effects of terrorism on FDI as a percentage of GDP. However, in contrast to many studies, we include country specific characteristics such as FDI restrictions to capture for the country specific conditions. The empirical evidence supports the idea that FDI decreases as a result of terrorism, as emphasized by Abadie and Gardeazabal (2005) among others. The baseline scenario for capturing the effects of terrorism on FDI is as follows:

$F D I / G D P=a_{0}+a_{1} G D P+a_{2} p o p+a_{3} \pi+a_{4} G G+a_{5}$ terrorism $+a_{6} R+a_{7} R E S+a_{8} D u m m y$

Whereas pop represent population over 65, RES FDI restrictions, and GDPinitial GDP per capita. The rest of variables are as mentioned earlier.

Total factor productivity (TFP) is among other macroeconomic variables, which is also affected by terrorism due to lower spillovers from foreign entrepreneurs to domestic ones. Moreover, the productivity dwindles as a result of anxiety and safety procedures at the airports, universities and public buildings. The baseline scenario for measuring the effects of the terrorism on total factor productivity is estimated through the following model.

$$
T F P=a_{0}+a_{1} w+a_{2} \pi+a_{3} \text { Schooling }+a_{4} G G+a_{5} \text { terrorism }+a_{6} R+a_{7} \text { oil }+a_{8} \text { Dummy }
$$

Where $w$ represents wage and oil stands for oil shock. Indeed, as proposed by Robert Gordon we include the oil shock in the productivity model to capture country specific shocks. The estimated results help us understand the effects of terrorism on total factor productivity.

\section{DATA}

The data we use are cross section data for 30 developed and developing countries in 2005. The sample includes; Australia, Austria, Belgium, Czech Republic, Denmark, Finland, France, Germany, Greece, Hungary, Iceland, India, Indonesia, Ireland, Italy, Japan, Korea, Malaysia, Mexico, Netherlands, Newzeland, Norway, Portugal, Slovakia Republic, Spain, Sweden, Switzerland, United Kingdom, United States, and Vietnam.

The data for FDI comes from the United Nation Conference on Trade and Development (UNCTAD). Our measure of country terrorism risk is the World Market Research Centre's Global Terrorism Index. We implement the country risk rating from the Moody's Institute. To measure the degree of openness of a country to foreign capital we use the index of capital flows and foreign investment restrictions published as a factor of the Index of Economic Freedom by the Heritage Foundation and the Wall Street Journal. The data on productivity comes from the OECD database. The Good Governance data represents the quality of government and is measured by an index constructed by Hall and Jones (1999) that evaluate countries on the basis of the institutions and government policies that determine the economic environment. This index is the average of two indices. First is an index of the quality of government institutions based on data assembled by Political Risk Services. The quality of government institutions is based on a comprehensive evaluation of each country's government institutions regarding: (1) law and order, (2) bureaucratic quality, (3) corruption, (4) risk of expropriation, and (5) government repudiation of the contracts. The 
second element composing the quality of the government is the extent to which a country is open to international trade. The idea is that protectionist governments are more likely to engage in policies that distort prices and undermine the ability of private sector to produce efficiently. The index of openness is that constructed by Sachs and Warner, which measure the fraction of years during the period of 1950 to 1990 that the country was open. We use an average of two index; the quality of government institutions and openness as the measure of the quality of governance, as proposed by Rivera Batiz (2005). This index ranges from 0 to 1 , with larger values indicating higher quality of governance. The rest of the variables come from the World Bank database.

\section{ESTIMATED RESULTS}

Using Generalized Method of Moment (GMM) technique the estimated results for the endogenous growth model are presented in Table (1). The results suggest that economic growth has been adversely and significantly affected by terrorism incidents. Interestingly enough, when the country risk and good governance are also included in the model (columns $3, \& 4$ ) still the results are robust, highlighting the devastating effects of terrorism on economic growth. Since the model is estimated in the logarithm form the coefficient on the terrorism incidents suggests that a standard deviation increase in the terrorism incident is associated with a fall in the economic growth by $0.13 \%$. Equivalently important, the magnitude of the coefficient on terrorism risk is almost as large as the coefficient on the country risk $(-14 \%)$. Nonetheless, the negative impact of inflation on economic growth is of higher magnitude (-23\%). The coefficients on good governance, capital stock, labor force and secondary schooling are all positive and significant at $5 \%$ level as expected by theory (column 4 ).

Table (2) represents the effects of terrorism incidents on FDI as a percent of GDP. The estimated results suggest that a standard deviation increase in the terrorism incidents reduces FDI as a percentage of GDP by $0.22 \%$ (column4). The magnitude of this coefficient is slightly smaller than the country risk, -0.25 . However, the inclusion of country's restrictions on FDI conjunctures that the magnitude of the coefficient on this variable is smaller than the coefficient on terrorism incident, highlighting the fact that terrorism affects the economic environment more than the regulatory framework.

Table (3) proves that terrorism has adversely and significantly affected total factor productivity worldwide. The results indicate that a standard deviation in terrorism incidents reduces TFP by $17 \%$, slightly more than the negative impact of inflation $-15 \%$ (column 2), underlining the devastating effect of terrorism on productivity. When we include such variables as oil shock, country risk and good governance, the terrorism coefficient is still robust ($15 \%)$ though slightly smaller than previous case. Interestingly enough, the coefficient on terrorism incidents (-15\%) is trivially lower than oil shock, $-17 \%$ (column4), emphasizing the importance of terrorism risk on productivity. Ironically, the coefficient on dummy variable is insignificant, indicating that there is not a meaningful difference between developing and developed world regarding the effects of terrorism on TFP.

\section{CONCLUDING REMARKS}

Estimating an endogenous growth model based on Generalized Method of Moment (GMM) technique we find significant negative association between terrorism and economic growth for a sample of both developed and developing countries. When good governance and country risk are also included in the model, the terrorism incident is still robust, underlining the devastating effects of terrorism on economic growth. The results suggest that a standard deviation increase in the terrorism incident is associated with a fall in the economic growth by $0.13 \%$. Ironically, the magnitude of the coefficient on terrorism is almost as large as the coefficient on country risk,

The estimated results also indicate that FDI as a percentage of GDP is significantly and negatively associated with terrorism incidents. A standard deviation in terrorism incident reduces the FDI over GDP by $0.22 \%$. The inclusion of country's restrictions on FDI in the model suggests that the coefficient on this variable is trivially smaller than terrorism incident, underlining the fact that terrorism affects the macroeconomic environment more than regulatory framework. 
The results also suggest that a standard deviation in terrorism incidents reduces TFP by $17 \%$, slightly larger than the negative impact of inflation $(-15 \%)$. When we include such variables as oil shock, country risk and good governance, the terrorism coefficient is still robust $(-15 \%)$. Interestingly enough, the coefficient on terrorism incident is negligibly lower than oil shock, $-17 \%$ (column4), highlighting the importance of terrorism on productivity. More importantly, the coefficient on terrorism is larger than the coefficient on inflation (-14\%) and country risk (-8\%), emphasizing the devastating effect of terrorism on productivity.

In sum, the results prove that terrorism not only has adversely and significantly affected economic growth, but has had significant negative impacts on FDI and TFP globally. In line with Abadie and Gardeazabal (2007) we find that once the effects of other country-specific characteristics such as country risk, good governance, oil shocks, and regulatory framework are taken into account the results are still robust.

\section{AUTHOR INFORMATION}

Hamid Shahrestani, a native of Tehran, Iran, is an Associate Professor of Economics at Ohio UniversityChillicothe. He received his B.A. in Economics from Concordia University in Canada, M.A. and Ph.D. in Economics from Western Michigan University and University of Cincinnati, respectively. In the past 30 years, he has been an active consultant in the private sector as well as a teacher and academic researcher. He can be reached by email at: $\underline{\text { Shahrest@ohio.edu }}$

Nahid Kalbasi Anaraki is an Assistant Professor of Economics at Islamic Azad University, Science and Research Branch in Tehran. She holds a Ph.D. in Economics from George Mason University in Virginia. Dr. Kalbasi is also an economic consultant for various manufacturing companies in Tehran. Her fields of interest are in International Economics and Monetary Theory.

\section{REFERENCES}

1. Abadie, Albetro (2004), "Poverty, Political Freedom, and Roots of Terrorism,"NBER, working paper No. 10859.

2. Abadie, Alberto and Javier Gardeazabal (2005), "Terrorism and the World Economy," Harvard University and NBER, Cambridge MA, University of Basque country, Spain.

3. Abadie, Alberto and Javier Gardeazabal (2003), "The Economic Cost of Conflict: A Case Study of the Basque Country," American Economic Review 93, 113-132.

4. Barro, Robert J., (1996), "Democracy and Economic Growth," Journal of Economic Growth, Volume 1, 127.

5. Barro Robert J., (1997), "Determinants of Economic Growth: A Cross-Country Empirical Study, Cambridge Massachusetts: The MIT Press.

6. $\quad$ Barth James R., Tong Li, Don McCarthy, Triphon Phumiwasana, and Glenn Yago (2006) "Economic Impacts of Global Terrorism, From Munich to Bali," Capital Studies, Milken Institute, Santa Monica, CA.

7. Becker, Gary and Kevin Murphy (2001), "Prosperity Will Rise Out of the Ashes, "Wall Street Journal, Oct 29, 2001, 14.

8. Becker, Gary and Yona Rubinstein (2004), "Fear and the Response to Terrorism: An Economic Analysis, "University of Chicago (www.ilr.cornell.edu/international/events/beckerrubinsteinpaper).

9. Easterly, William and Rose Levine, (2001) "It's Not Factor Accumulation: Stylized Facts and Growth Models," The World Bank Economic Review, 15, 177-219.

10. Enders, Walter and Todd Sandler (1996), "Terrorism and Foreign Direct Investment in Spain and Greece," Kyklos 49 (3), 331-352.

11. Enders, Walter, Todd Sandler and Gerald F. Parise (1992), "An Econometric Analysis of the Impact of Terrorism on Tourism," Kyklos 45, 531-554.

12. Freedom House, Freedom in the World: The Annual Survey of Political Rights and Civil Liberties, 199697, Transaction Publishers, New Jersey 1997.

13. Frey, Bruno S., Simon Luechinger and Alois Stutzer (2004), "Calculating Tragedy: Assessing the Costs of Terrorism,” Institute for Empirical Research in Economics, University of Zurich, Working Paper 205. 
14. Global Business Policy Council (2004), "FDI Confidence Index," A.T. Kearney, Alexandria, Virginia.

15. Grossman, Gene M. and Elhanan Helpman (1991), "Innovation and Growth in the Global economy, Cambridge," Mass. MIT Press.

16. IMF (2001), "How Has September 11 Influenced the Global Economy?" World Economic Outlook, International Monetary Fund, Washington D.C.

17. IMF (2007), World Economic Outlook database, Washington D.C. Oct 2007.

18. Kaufmann, Daniel, Aart Kraay and Massimo Mastruzzi (2004), "Governance Matters III: Governance Indicators for 1996-2002," World Bank Economic Review 18, 253-287.

19. Krueger, Alan B. and David D. Laitin (2003) "Kto Kogo? A Cross-Country Study of the origins and Targets of Terrorism," Princeton University and Stanford University, (www.krueger.princeton.edu)

20. Levine Ross, (2001) "International Financial liberalization and Economic Growth," Review of International economics, 9, 688-702.

21. Mauro, Paolo (1995), “Corruption and Growth,” Quarterly Journal of Economics 110 (3), $681-712$.

22. Miles, Marc A., Edwin J. Feulner, Jr., Mary Anastasia O’ Grady and Ana I. Eiras (2004), "Index of Economic Freedom," Washington D.C. the Heritage Foundation and Wall Street Journal.

23. OECD (2002), Economic consequences of terrorism, Economic Outlook 71, 118-133.

24. Rivera-Batiz Francisco, (1999) "Democracy, Governance and Economic Growth: Theory and Evidence", New York, Department of Economics, Columbia University.

25. Rivera Batiz Francisco, (2001) "International Financial Liberalization, Corruption and Economic Growth, Review of International Economics, 9, 723-731.

26. Sandler Todd and Walter Enders, (2005) " Economic consequences of terrorism in developed and developing countries: An overview," University of Southern California and University of Alabama (www.cba.ua.edu).

27. United States Congress, Joint Economic committee (2002), "The Economic Costs of Terrorism.”

Table (1) Baseline specifications for GDP Growth

Dependent variable: Economic Growth

\begin{tabular}{|c|c|c|c|c|}
\hline & (1) & (2) & (3) & (4) \\
\hline Constant & $\begin{array}{l}1.44 * * \\
(0.56)\end{array}$ & $\begin{array}{l}1.23^{*} \\
(0.73)\end{array}$ & $\begin{array}{l}3.6^{* * *} \\
(0.04)\end{array}$ & $\begin{array}{l}4.1 * * \\
(0.56)\end{array}$ \\
\hline Terrorism incident & $\begin{array}{c}-0.12 * * \\
(0.03)\end{array}$ & $\begin{array}{c}-0.17 * * \\
(0.027)\end{array}$ & $\begin{array}{l}-0.14^{*} \\
(0.08)\end{array}$ & $\begin{array}{c}-0.13 * * \\
(0.06)\end{array}$ \\
\hline Capital stock & $\begin{array}{l}0.97 * \\
(0.51)\end{array}$ & $\begin{array}{c}0.96 * * \\
(0.23)\end{array}$ & $\begin{array}{c}0.85^{* *} \\
(0.17)\end{array}$ & $\begin{array}{c}0.74 * * \\
(0.15)\end{array}$ \\
\hline Labor force & $\begin{array}{l}0.04 * * \\
(0.02)\end{array}$ & $\begin{array}{l}0.07 * \\
(0.04)\end{array}$ & $\begin{array}{l}0.11^{*} \\
(0.07)\end{array}$ & $\begin{array}{l}0.23 * * \\
(0.12)\end{array}$ \\
\hline Secondary schooling & $\begin{array}{l}0.17^{*} \\
(0.10)\end{array}$ & $\begin{array}{l}0.15^{* *} \\
(0.08)\end{array}$ & $\begin{array}{c}0.09 \\
(0.07)\end{array}$ & $\begin{array}{l}0.08^{*} \\
(0.05)\end{array}$ \\
\hline Inflation & & $\begin{array}{l}-0.35 \\
(0.21)\end{array}$ & $\begin{array}{c}-0.19 * * \\
(0.09)\end{array}$ & $\begin{array}{l}-0.23 * \\
(0.14)\end{array}$ \\
\hline Country risk & & & $\begin{array}{l}-0.12 * \\
(0.07)\end{array}$ & $\begin{array}{l}-0.14 * \\
(0.08)\end{array}$ \\
\hline Good Governance & & & & $\begin{array}{l}0.29 * \\
(0.17)\end{array}$ \\
\hline R-squared & 0.56 & 0.61 & 0.68 & 0.72 \\
\hline
\end{tabular}

Standard errors in parentheses.

** indicates statistical significance at $5 \%$ level.

* indicates statistical significance at $10 \%$ level. 
Table (2) Baseline specifications for FDI

Dependent variable: FDI as a percentage of GDP

\begin{tabular}{|c|c|c|c|c|}
\hline & (1) & $(2)$ & (3) & $(4)$ \\
\hline \multirow[t]{2}{*}{ Constant } & $16.7 * *$ & 14.5 & $11.57 *$ & 0.87 \\
\hline & $(0.89)$ & $(12.3)$ & $(7.25)$ & $(0.51)$ \\
\hline \multirow[t]{2}{*}{ Terrorism incident } & $-0.18 *$ & $-0.21 * *$ & $-0.19 * *$ & $-0.22 * *$ \\
\hline & $(0.11)$ & $(0.12)$ & $(0.06)$ & $(0.08)$ \\
\hline \multirow[t]{2}{*}{ GDP per capita } & & $0.17 *$ & $0.11^{* *}$ & $0.13 * *$ \\
\hline & & $(0.11)$ & $(0.06)$ & $(0.04)$ \\
\hline \multirow[t]{2}{*}{ Population over 65} & -0.012 & -0.36 & $-0.25 *$ & $-0.16^{* *}$ \\
\hline & $(0.72)$ & $(.023)$ & $(0.14)$ & $(0.05)$ \\
\hline \multirow[t]{2}{*}{ Country risk } & 0.034 & -0.27 & -0.31 & $-0.25 * *$ \\
\hline & $(0.02)$ & $(0.18)$ & $(0.22)$ & $(0.03)$ \\
\hline \multirow[t]{2}{*}{ Inflation } & & $-0.25 * *$ & $-0.68 *$ & $-0.37 * *$ \\
\hline & & $(0.12)$ & $(0.41)$ & $(0.19)$ \\
\hline \multirow[t]{2}{*}{ FDI restrictions } & & & $-0.39 * *$ & $-0.19 * *$ \\
\hline & & & $(0.16)$ & $(0.09)$ \\
\hline \multirow[t]{2}{*}{ Good Governance } & & & 0.011 & $0.12 *$ \\
\hline & & & $(0.47)$ & $(0.02)$ \\
\hline \multirow[t]{2}{*}{ Dummy } & & & & 0.14 \\
\hline & & & & $(0.13)$ \\
\hline R-squared & 0.59 & 0.68 & 0.77 & 0.81 \\
\hline
\end{tabular}

Standard errors in parentheses.

** indicates statistical significance at $5 \%$ level.

* indicates statistical significance at $10 \%$ level.

Table (3) Baseline specifications for Total Factor Productivity

Dependent variable: Total Factor Productivity (TFP)

\begin{tabular}{|c|c|c|c|c|}
\hline & (1) & $(2)$ & (3) & (4) \\
\hline \multirow[t]{2}{*}{ Constant } & 0.26 & 1.74 & $2.35^{*}$ & $18.64 * *$ \\
\hline & $(1.23)$ & $(1.05)$ & $(1.45)$ & $(2.67)$ \\
\hline \multirow[t]{2}{*}{ Terrorism incident } & -0.34 & $-0.17 *$ & -0.21 & $-0.15 * *$ \\
\hline & $(1.23)$ & $(0.11)$ & $(0.78)$ & $(0.06)$ \\
\hline \multirow[t]{2}{*}{ Wage } & $0.16 * *$ & 0.57 & $0.42 * *$ & $0.16^{*}$ \\
\hline & $(0.08)$ & $(1.2)$ & $(0.21)$ & $(0.10)$ \\
\hline \multirow[t]{2}{*}{ Inflation } & $-0.24 * *$ & -0.15 & $-0.81 * *$ & $-0.14 *$ \\
\hline & $(0.12)$ & $(0.23)$ & $(0.37)$ & $(0.08)$ \\
\hline \multirow[t]{2}{*}{ Secondary schooling } & 0.48 & $0.029 *$ & $0.026 *$ & $0.098 *$ \\
\hline & $(0.71)$ & $(0.018)$ & $(0.017)$ & $(0.057)$ \\
\hline \multirow[t]{2}{*}{ Oil shock } & & $0.21 *$ & $-0.14 * *$ & $-0.17 *$ \\
\hline & & $(0.14)$ & $(-0.05)$ & $(0.09)$ \\
\hline \multirow[t]{2}{*}{ Country risk } & & & $-0.027 *$ & -0.08 \\
\hline & & & $(0.15)$ & $(0.06)$ \\
\hline \multirow[t]{2}{*}{ Good Governance } & & & & $0.11 *$ \\
\hline & & & & $(0.06)$ \\
\hline \multirow[t]{2}{*}{ Dummy } & & & & $0.18 * *$ \\
\hline & & & & $(0.11)$ \\
\hline R-squared & 0.67 & 0.73 & 0.81 & 0.85 \\
\hline
\end{tabular}

Standard errors in parentheses.

** indicates statistical significance at $5 \%$ level.

* indicates statistical significance at $10 \%$ level. 


\section{NOTES}

